\title{
TACTICS, STRATEGIES AND FIGHTING SPECIFIC OF THE COHORTES EQUITATAE IN ROMAN DACIA
}

Petru Ureche

Tactici, strategii şi specific de luptă al cohortelor equitate în Dacia Romană

Armata romană este renumită pentru abilitatea de a evolua în funcție de schimbările cerințelor politice şi militare ale perioadei imperiale şi a se adapta condițiilor locale în scopul de a înfrânge aproape orice oponent.

Romanii au înțeles că legiunile nu erau cele mai utile trupe în operațiuni care necesitau forțe care se deplasează rapid sau în lupte pe teren dificil sau muntos, acestea fiind mult mai potrivite pentru asedii şi lupte plănuite. Astfel, în conflictele la scară mică şi pentru menţinerea securităţii interne şi de frontieră, flexibilitatea tactică oferită de trupele auxiliare s-a dovedit extrem de utilă.

Acest studiu prezintă şi analizează organizarea şi tacticile utilizate de cohortele equitate - trupe mixte de infanterie şi cavalerie, cu o privire specială asupra celor care au fost prezente şi în Dacia. Analiza s-a făcut atât din punctul de vedere al specificului de luptă al populațiilor care alcătuiau cohortele equitate, cât şi din cel al locului în care aceste trupe au fost cantonate.

Key words: mounted cohorts, tactics, fighting particularities.

This study presents and analyses the style and fighting tactics tackled by the cohortes equitatae $^{1}$ of the Roman army, with special attention to those that were garrisoned in Dacia, as well. The purpose of the paper is to broach this subject from the point of view of the populations that enter the structure of these troops and of the place the unit was quartered ${ }^{2}$.

The Romans understood the necessity to have soldiers with different fighting skills, creating the auxiliary troops to support the legions ${ }^{3}$, but, shortly after, these troops became complementary to them ${ }^{4}$. The fighting tactic and the force of the troops on the limes were determined by the geographical conditions and by the nature of the enemy they were facing 5 .

For most of the limes zones infantry troops were used in the night watch and guard towers, as well as cavalry, floating troops, were used for patrol, as escorts or to stop and thwart barbarian raids ${ }^{6}$. This is the reason why during the Julio-Claudian dynasty ${ }^{7}$ a new type of troops was introduced to fulfill these requests. These miscellaneous troops are called cohortes equitatae $^{8}$. Their introduction was possible due to the flexibility of the Roman military system that allowed structure and number modifications of the soldiers in a troop depending on the circumstances they had to act ${ }^{9}$.

\footnotetext{
${ }^{1}$ For regular cohorts see Ureche 2009.

${ }^{2}$ I want to thank dr. Cristian Găzdac for his support and for the digitized version of the map.

${ }^{3}$ Găzdac 1997, 152.

${ }^{4}$ Luttwak 1976, 41.

${ }^{5}$ Gudea 1979, 65-66.

${ }^{6}$ Lutwak 1976, 123, Peddie 1996, 76.

${ }^{7}$ Dixon, Southern 1992, 26.

${ }^{8}$ Cichorius IV. 1, 235; Cheesman 1914, 28; Davies 1989, passim.

${ }^{9}$ Goldsworthy 1996, 13 .
} 
The mounted cohorts, alongside the other auxiliary troops were extremely efficient units within an army in which different types of troops made up special groups with well-defined functions ${ }^{10}$. Besides the campaigns, they could successfully oppose the barbarian population raids or eliminate the latrones bands ${ }^{11}$. The equitatae cohorts rapidly became extremely useful troops. Their number soon exceeded that of the ordinary cohorts ${ }^{12}$. The same happened in Roman Dacia, where 22 are mounted cohorts ${ }^{13}$.

As far as the manpower of these troops is concerned, sources offer somehow contradictory information. Thus, Hyginus specifies that within the cohortes equitatae milliariae there were 240 horsemen and 760 infantrymen, and in the quingenariae ones there were 120 horsemen and 380 infantrymen ${ }^{14}$. However, Josephus speaks in his reports on the Judaic War about a mounted cohort that had 120 horsemen and 600 infantrymen ${ }^{15}$. This apparent contradiction is explained by the fact that the number of soldiers and the structure of the troop were influenced by the type of conflict in the area they were stationed ${ }^{16}$, the recruitment capacities, the lost battles or the necessity of sending out in mission vexillations ${ }^{17}$. A troop had never a complete manpower.

G. L. Cheesman considered the cohortes equitatae as being horseback infantry troops, not very well trained, that rode weak horses. Likewise, he thought that those soldiers walked to the battle field, then dismounted and fought as infantrymen ${ }^{18}$. This affirmation was contradicted by numerous arguments being brought to it. Thus, if within the cohortes equitatae the manpower of the troops was not complete, the cavalry detachments were much closer to the theoretic number of soldiers that they had to have to the infantry's detriment ${ }^{19}$. This was possible due to the fact that the infantrymen could be promoted to equites later on ${ }^{20}$. Turning from infantrymen to horsemen was only possible after a few years of service and only if the soldier proved to be qualified. He was trained before becoming a horseman, thus he was not just an infantryman on horseback, but a real horseman in the true sense of the word ${ }^{21}$.

Another counterargument to Chessman's affirmation is the fact that by turning from infantryman to horseman the soldier's pay rose ${ }^{22}$. The Romans' pragmatism of not spending too much money on week detachments it is well-known.

Arrian used the equites cohortales alongside the ala $^{23}$, not with infantrymen in the cohorts or legions. Consequently, the equites were not divided from the point of view of membership

\footnotetext{
${ }^{10}$ Ruscu 1996, 227.

${ }^{11}$ Southern 1989, 125.

${ }^{12}$ Davies 1989, 141.

${ }_{13}$ Petolescu 1995b, 237-275.

${ }^{14}$ Hyginus 26, 27: 26. Habet itaque cohors equitata miliaria equites CCXL, quod redigo ad peditem, ut pedem, quod a accipit miles, redigo ad duo semis, quod accipit eques. Fit, dimidia sumpta, ductum quinquies. Sic tractabimus numerum equitum. Fit CXX, quinquies, fit DC. Accedunt ex ea cohorte miliaria, detractis equitibus, reliqui pedites $D C C L X$; fit cum superiore CI)CCCLX. Meminerimus itaque, ad computationem cohortis equitatae miliariae pedaturam ad CI)CCCLX dari debere. 27. Cohors equitata quingenaria in dimidio eandem rationem continet quam cohors [miliaria]. Habet itaque cohors equitata miliaria centurias $X$ peditum, equites CCXL, turmas X, omnes tendunt papilionibus $C X X X V I$, ex eis centuriones et decurionessingulis papilionibus utuntur. Cohors equitata quingenaria habet centurias VI, reliqua pro parte dimidia.

${ }^{15}$ Josephus 3.4.2.

${ }^{16}$ Goldsworthy 1996, 24.

${ }^{17}$ Goldsworthy 1996, 13.

${ }^{18}$ Cheesman 1914, 29.

${ }^{19}$ Davies 1989, 146.

${ }^{20}$ Goldsworthy 1996, 23.

${ }^{21}$ Davies 1989, 145-146.

${ }^{22}$ Breeze 1971, Speidel 1973, passim.

${ }^{23}$ Arrian 11, 20, apud Ruscu 1996, 210.
} 
to alae or to cohorts ${ }^{24}$, but from the point of view of the type of weapons they were using as proven by the funerary monuments in the same way as the alae and using the same tactics as them ${ }^{25}$.

Chessman still cannot be accused of having made unfounded affirmations because the soldiers that did not enter the alae because they did not meet the height criteria were accepted in cohorts and could turn to equites cohortales ${ }^{26}$. The quality of the training of horses and the equipment were in agreement with the pay, and because the equites in the cohorts were paid less than the ones in the alae, they were not that well equipped ${ }^{27}$. These things lead to the fact that the equites cohortales represented a second line of cavalry as compared to the equites alares ${ }^{28}$.

There were some cases where the equitate troops had to dismount and fight as infantrymen when the difficulties of the ground stopped them from fighting on horseback ${ }^{29}$. In the forests ${ }^{30}$ or in the areas with steep slopes, the dismounted equites were more agile than the legionaries or the auxiliary infantrymen due to their lighter equipment, but the cases where the horsemen that fought as infantrymen were always exceptions to the rule, being the result of terrain conditions ${ }^{31}$.

The horsemen in the equitate cohorts had to deliver messages, go in recognition actions or escort the infantry or the convoys that moved slowly, supply with animals for sacrifice or fight in the amphitheatres, collect the taxes or, together with the infantry, they had roles of garrisons or checking points ${ }^{32}$.

The cohortes equitatae were usually placed in the front line of the limes (see map 1), alongside the cohortes peditatae, while the alae were a little behind to be able to operate on a wider area.

The mounted cohorts were recruited from the populations well-known for their agility and ability to ride horses. The most well represented populations in these troops were: the Gauls, the Hispanians, the Pannonians, the Thracians and the Orientals.

The most famous auxiliary troops, and the first to be used by the Romans, were the Gallic ones, whose skill was known to the Romans since the wars with Hannibal ${ }^{33}$. They were considered the best horsemen fighters of their time ${ }^{34}$, being used by Caesar in his campaigns against the Helvetii ${ }^{35}$. In Vespasian's time the Gauls were very much appreciated. Most of them were horsemen, for the alae, as well as for the cohortes equitatae recruited from Gallia ${ }^{36}$.

The Gauls were armed with a spatha, a spear and a shield. The last one wasn't very wide and its surface was flat not curved, that's why it didn't offer too much protection to the soldiers ${ }^{37}$. The fighting tactic of the Gallic cavalry, which consisted in throwing the spears while

\footnotetext{
${ }^{24}$ Ruscu 1996, 214.

${ }^{25}$ Davies 1989, 143.

${ }^{26}$ Davies 1989, 145-146.

${ }^{27}$ Davies 1989,142 .

${ }^{28}$ Davies 1989, 145.

29 Frontinus 2.3.23: Imperator Caesar Augustus Germanicus, cum subinde Chatti equestre proelium in silvas refugiendo deducerent, iussit suos equites, simulatque ad impedita ventum esset, equis desilire pedestrique pugna confligere; quo genere consecutus, ne quis iam locus victoriam eius moraretur.

${ }^{30}$ Tacitus 37: Quod ni frequens ubique Agricola validas et expeditas cohortis indaginis modo et, sicubi artiora erant, partem equitum dimissis equis, simul rariores silvas equitem persultare iussisset, acceptum aliquod vulnus per nimiam fiduciam foret.

${ }^{31}$ Davies 1989, 144-145.

${ }^{32}$ Davies 1989, 146-148.

${ }^{33}$ Hyland 1993, 91.

${ }^{34}$ Strabo 4.4.2.

${ }^{35}$ Peddie 1996, 49

${ }^{36}$ Hyland 1993, 91 .

${ }^{37}$ Peddie 1996, 82.
} 
riding their horses, could not be successful against the heavy cavalry units, the battle at Carrhae being an example of their powerlessness ${ }^{38}$. The horses the Gauls used were famous for their speed and height. The breed was obtained from crossing the Gallic horses with the ones in Italy ${ }^{39}$.

The Gauls were high-spirited and quick for battle, "ready to throw themselves into danger without having any other support in their fight than their own force and bravery", but "they come together all at once for the struggle, both openly and without circumspection, so that for those who wish to defeat them by stratagem they become easy to deal with"40.

The Gallic troops could be relatively "purely" ethnic or combined with other populations well-known for their abilities in riding horses and weapon handling. Among the Gallic cohortes equitatae in Dacia the first category was made up of the cohors II Gallorum Macedonica or cohors II Gallorum, while the second was composed of the cohors II Gallorum Pannonica ${ }^{41}$ and the cohors V Gallorum et Pannoniorum equitata ${ }^{42}$. There were many troops where Gauls were mixed with Pannonians. The last ones were considered by the Romans as being the bravest men they had ever met $^{43}$. This was the reason they were recruited and used in the Roman army starting with the early age of the Republic, taking the third place in the number of cavalry troops in this army, after Gauls and the Hispanians ${ }^{44}$. Unfortunately at the moment, the place where the first two of the mounted cohorts in Dacia were garrisoned has not been found. The third one stationed in the garrison of Pojejena ${ }^{45}$.

The second place, as far as the number of troops in the Roman army is concerned, is taken by the Hispanians, famous for their courage, almost bestial insensibility and ferocity ${ }^{46}$. The Romans encountered the Hispanic troops first as enemies in the battle at Cannae, later on to be used by Caesar in Gallia against Vercingetorix ${ }^{47}$.

Unlike the Gauls, the Hispanians did not engage in decisive battles, fighting all the time in a different place and using a tactic similar to the one used by thieves ${ }^{48}$. This was possible because of the quick and obedient horses they used ${ }^{49}$.

One of the tactics they used was that of two warriors riding the same horse, in battles one of them dismounting and fighting on foot, as an infantryman ${ }^{50}$. This tactic explains also the great number of Hispanians cohortes equitatae, four, in Dacia: cohors I Hispanorum Veterana equitata, cohors I Flavia Ulpia Hispanorum milliaria c. R. equitata, cohors II Hispanorum scutata Cyrenaica equitata, cohors IIII Hispanorum equitata ${ }^{51}$.

The Hispanic troops were placed in areas of great importance to the defensive system of the province, especially in the fortresses on the border zones that supervised and dealt with barbarian horse riding populations ${ }^{52}$. This way there were two troops in the west of the Dacian limes: at Micia (ala I Hispanorum Campagonum) ${ }^{53}$ and Bologa (cohors II Hispanorum scutata

\footnotetext{
${ }^{38}$ Hyland 1990, 181.

${ }^{39}$ Hyland 1990, 21.

${ }^{40}$ Strabo 4.4.2.

${ }^{41}$ Petolescu 1995b, 256.

${ }^{42}$ Petolescu 2002, 108.

${ }^{43}$ Dio Cassius 59.36, apud Găzdac 1997, 153.

${ }^{44}$ Găzdac 1997, 153.

${ }^{45}$ Petolescu 2002, 108.

${ }^{46}$ Strabo 3.4.17.

${ }^{47}$ Hyland 1990, 14.

${ }^{48}$ Strabo 4.4.2.

${ }^{49}$ Strabo 3.4.15.

${ }^{50}$ Strabo 3.4.18.

${ }^{51}$ Russu 1969, 148, Zahariade 1976, passim.

${ }^{52}$ Zahariade 1976, 491.

${ }^{53}$ Zahariade 1976, 483; Bejan 1998, 39.
} 
Cyrenaica equitata) $)^{54}$; two in the north - at Românaşi (cohors I Hispanorum Pia Fidelis) ${ }^{55}$ and Odorheiul Bistriței (cohors I Flavia Ulpia Hispanorum equitata) ${ }^{56}$; one in the east - at Inlăceni (cohors IIII Hispanorum equitata) $^{57}$; two on the limes alutanus - at Hoghiz (ala I Asturum) ${ }^{58}$ and Slăveni (ala I Hispanorum $)^{59}$ and two on the limes transalutanus - cohors I Hispanorum Veterana equitata at Brețcu (Angustiae) and Comalău and cohors I Bracaraugustanorum at Brețcu (Angustiae) ${ }^{60}$, but here, we will refer in detail to the mounted cohorts only.

The fortress in Bologa, that can be found on the Crişul Repede Valley, at its confluence with the Sebeş, guarded the entrance in the province through this valley. The fortress dominated the entire valley at a long distance ${ }^{61}$. The troop that was garrisoned here, cohors II Hispanorum scutata Cyrenaica equitata, received the epithet scutata, which meant that the soldiers of this troop had the right to wear a legionary scutum instead of an auxiliary clipeus ${ }^{62}$.

Orheiul Bistriței (cohors I Flavia Ulpia Hispanorum milliaria c. R. equitata) ${ }^{63}$, together with Livezile, Ilişua and Căşeiu supervised the northern limes, being destined to stop the attacks of the so-called Free Dacians ${ }^{64}$.

Cohors III Hispanorum equitata from Inlăceni controlled the territory between the upper part of the two Târnave ${ }^{65}$.

The troops quartered in Brețcu controlled the passing road within the province towards East, and the one in Comalău controlled the commercial road on the Black River Valley in the east ${ }^{66}$.

It was said that the Britons were the population that had no fear for their lives ${ }^{67}$ and for this very reason they gave a lot of troops to the Empire even before the Flavian dynasty ${ }^{68}$. Four cohorts of Britons activated in Dacia, one of them was equitata: cohors I Brittonum milliaria, and the others were peditatae: cohors I Augusta Nerviana Pacensis Brittonum milliaria, cohors II Augusta Nervia Pacensis Brittonum milliaria ${ }^{69}$, and cohors I Aurelia Brittonum milliaria ${ }^{70}$.

The Britons used big, heavy, blunt swords to fight, a thing that did not give them any advantage in fighting man against man. They preferred to fight from distance relying on throwing spears ${ }^{71}$.

There were two more equitate cohorts that came from Britannia on the northern Dacian limes - cohors I Britannica milliaria $c$. R. equitata, which was stationed in the fortress in Căşeiu ${ }^{72}$ and cohors II Britannica milliaria, which settled down in the west of the province, in

\footnotetext{
${ }^{54}$ Zahariade 1976, 480; Bejan 1998, 40.

${ }^{55}$ Bejan 1998, 40, Zahariade 1976, 479.

${ }^{56}$ Zahariade 1976, 480.

${ }^{57}$ Petolescu 1995b, 264

${ }^{58}$ Zahariade 1976, 485.

${ }^{59}$ Zahariade 1976, 486.

${ }^{60}$ Petolescu 2002, 85.

${ }^{61}$ Zahariade 1976, 492.

62 Zahariade 1976, 480.

${ }^{63}$ Zahariade 1976, 480.

${ }^{64}$ Zahariade 1976, 492.

${ }^{65}$ Zahariade 1976, 492.

${ }^{66}$ Zahariade 1976, 492.

${ }^{67}$ Tacitus 37: Et Britanni, qui adhuc pugnae expertes summa collium insederant et paucitatem nostrorum vacui spernebant, degredi paulatim et circumire terga vincentium coeperant...

${ }^{68}$ Marcu 2004, 219.

${ }^{69}$ Petolescu 1995b, 245.

${ }^{70}$ Petolescu 2002, 92.

${ }^{71}$ Tacitus, 36: ... simulque constantia, simul arte Britanni ingentibus gladiis et brevibus caetris missilia nostrorum vitare vel excutere, atque ipsi magnam vim telorum superfundere...quod et ipsis vetustate militiae exercitatum et hostibus inhabile [parva scuta et enormis gladios gerentibus]; nam Britannorum gladii sine mucrone complexum armorum et in arto pugnam non tolerabant.

${ }^{72}$ Petolescu 1995b, 242.
} 
Romita $^{73}$ after they built the fortress in Căşeiu ${ }^{74}$ and participated in building the one from Ilişua $^{75}$ or at least by bringing the necessary materials ${ }^{76}$. Dan Isac and Felix Marcu believe that the name of this troop was actually cohors II Britannorum milliaria ${ }^{77}$.

The Thracians were also found amongst the Empire troops, especially in the cohortes equitatae, being known as a horse rider population. The troops in Dacia were: cohors I Thracum, cohors VI Thracum equitata, cohors I Thracum c. R., cohors I Thracum Sagittariorum and cohors II Flavia Bessorum.

It is only known about the first two to be equitatae. There is very few information regarding the place where they set camp. Thus, cohors I Thracum was present in the province only during Trajan's time, when it was stationed on limes alutanus, in Acidava, and then it was moved to Moesia Inferior ${ }^{78}$. As far as cohors VI Thracum equitata is concerned, we may say that they activated on the western and north-western Dacian limes, because their stamped bricks have been found at Porolissum, Românaşi and Romita ${ }^{79}$.

Another well-known type of cohortes equitatae was the one set up with Oriental archers. Cohors II Flavia Commagenorum sagittaria was amongst the troops that operated in Dacia. It is also possible that cohors I Flavia Commagenorum was an equitata and sagittaria cohort too $^{80}$, this population being skilled in using the bows and riding horses, most of the Commagenian cohorts being sagittaria, and the Syrians - one of the populations "born in the saddle".

The archers had to support other troops, standing behind them and shooting above them. They were usually used to offer support to the heavy infantry against the attacks of the cavalry, but they could not resist an attack by themselves ${ }^{81}$. Titus used them in the street fights during the siege of Jerusalem, placing them at the end of the streets ${ }^{82}$.

The archers on foot used bigger and stronger bows, this way having a wider shooting range than that of the archers on horses ${ }^{83}$, because the riders lacked stability, their shooting platform being the horse saddle not the ground. Still, the riders could take action quicker on a larger surface due to their increased mobility. The riders in the cohortes equitatae of sagittarii fought using the same type of equipment as the ones in the alae $^{84}$.

As a moving horse represents a very unstable "shooting platform", the accuracy of an archer at a gallop shooting a precise target was pretty diminished. That is why his purpose in that moment was not to hit a specific target but to send as many arrows as possible towards the enemy so that some of them could find their target. The speed of shooting took the place of precision in these situations ${ }^{85}$.

Whether on foot or on horseback, all the archers in the Roman army used the Mediterranean technique of shooting. The bow was held in the left hand, which was straightened ahead, and the right hand bent the bow spring up to the chin before releasing it. While being bent, the bow spring was held with a finger above the arrow and with one or two fingers under it ${ }^{86}$.

\footnotetext{
${ }^{73}$ Petolescu 1995b, 243-244.

${ }^{74}$ Isac 2003, 33.

${ }_{75}^{75}$ Protase 1985, 250, note 15, apud Isac 2003, 34.

${ }^{76}$ Isac 2003, 34.

${ }^{77}$ Isac, Marcu 1999.

${ }^{78}$ Petolescu 1995b, 269-270.

${ }^{79}$ Petolescu 1995b, 271.

${ }^{80}$ Petolescu 1995b, 250.

${ }^{81}$ Goldsworthy 1996, 190.

82 Josephus, 5.8.1.

${ }^{83}$ Coulston 1985, 245-6, apud Dixon, Southern 1992, 53.

${ }^{84}$ Davies 1989, 143.

${ }^{85}$ Goldsworthy 1996, 67.

${ }^{86}$ Goldsworthy 1996, 185.
} 
Cohors II Flavia Commagenorum sagittaria was stationed at Micia ${ }^{87}$, where together

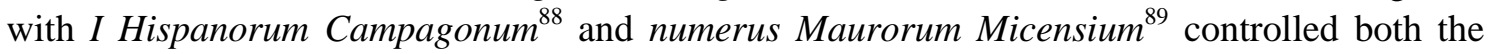
Mureş Valley up to Partiscum and Apulum and the golden mines zone in the Apuseni Mountains. Attacks of the Iazyges were possible on Mureş Valley; this was the main sailing artery of Dacia ${ }^{90}$. Proof of cohors I Flavia Commagenorum being stationed was found on the limes alutanus in Slăveni, Romula and Acidava ${ }^{91}$; it was positioned in front of the Free Dacian and Sarmatian tribes.

Cohors I Alpinorum equitata and cohors I Ubiorum were stationed on the eastern limes, in Sărățeni and Călugăreni ${ }^{92}$, respectively Odorheiul Secuiesc ${ }^{93}$. These troops, together with cohors IIII Hispanorum equitata from Inlăceni controlled the upper flows of the two Târnave. Cohors II Flavia Numidarum was also stationed on the eastern border, on limes alutanus. This troop settled down in the fortress at Feldioara ${ }^{94}$ on the Transylvanian Olt. Troops of Numidians were used ever since Caesar's time ${ }^{95}$. The troop in Dacia, being an equitata one, was positioned in front of the Free Dacian tribes whose attacks they could counteract more easily.

Cohors VIII Raetorum equitata stationed in the Teregova ${ }^{96}$ fortress in the west of Dacia.

According to D. Benea, it could be possible that all soldiers of the troops stationing at Tibiscum were recruited in the East and then, at the place, they were divided to the units according to various necessities ${ }^{97}$. This theory is supported by the case below. Cohors I Vindelicorum milliaria equitata c. R. settled down in Tibiscum; it was a Celtic troop with Oriental elements as well. A Palmyrean was able to reach the position of a centurion in this cohort ${ }^{98}$.

Cohors III Delmatarum milliaria equitata $c$. $R$. was also stationed in this area, at Mehadia, to control the road sector Dierna - Tibiscum ${ }^{99}$.

By creating the cohortes equitatae, the Roman Empire obtained an inexpensive cavalry force that could even take the place of the well trained alae, if necessary. Likewise, the making of these troops solved the necessity of the presence of some infantrymen troops in the watch and guard towers, as well as of some mobile, cavalry troops, used for patrol, escorts or to stop and cross the barbarians' raids.

\section{BIBLIOGRAPHY}

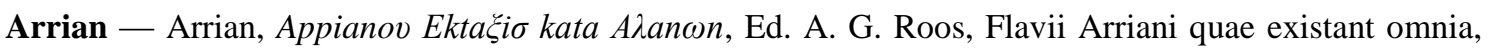
volumen II, Scripta minora et fragmenta, 1928, 177-185; Ruscu 1996 - D. Ruscu, Ligia Ruscu, „EKTA $\Xi I \Sigma$ KATA A $\Lambda$ AN $\Omega N$ ” lui Arrian şi strategia defensivă a Imperiului Roman epocă hadrianică, EN 6, 1996, 205-235.

Caesar - Caesar, De Bello Gallico, L.-A. Constans, César, Guerre des Gaules, (Les Belles Lettres), Paris, 1954-1955.

Cassius Dio - Cassius Dio, Roman History, E. Cary, Dio's Roman History, I - VIII, (Loeb). London and Cambridge, 1914-1925.

\footnotetext{
${ }^{87}$ Petolescu 1995b, 250.

${ }^{88}$ Petolescu 1995a, 43.

${ }^{89}$ Petolescu 2002, 136; Benea 1985, 149.

${ }^{90}$ Zahariade 1976, 492.

${ }^{91}$ Petolescu 1995b, 250.

${ }^{92}$ Petolescu 1995b, 239.

${ }^{93}$ Petolescu 1995b, 272.

${ }^{94}$ Petolescu 1995b, 239.

${ }^{95}$ Caesar, II. 7.

${ }^{96}$ Petolescu 1995b, 268.

${ }^{97}$ Benea 1980, 138.

${ }^{98}$ Piso $1979,139$.

${ }^{99}$ Petolescu 2002, 102.
} 
Frontinus - Frontinus, Stratagemata, Ch. E. Bennett, Frontinus, The Stratagems and The Aqueducts of Rome, (Loeb). London and New York, 1925.

Hyginus - Hyginus, De munitionibus castrorum; M. Lenoir, Pseudo-Hygin. Des fortifications du camp, Paris, 1979.

Josephus - Josephus Flavius, The Jewish War, H. St. J. Thackeray, Josephus II - III, The Jewish War, Loeb). London and Cambridge, 1956-1961.

Strabo - Strabo, Geografia, H. L. Jones, The Geography of Strabo, I - VIII, (Loeb). London and Cambridge, 1960-1967.

Tacitus - Tacitus, De vita et moribus Iulii Agricolae, M. Hutton, Dialogus. Agricola. Germania, (Loeb). London and New York, 1914.

Bejan 1998 - A. Bejan, Dacia Felix. Istoria Daciei Romane, Timişoara.

Benea 1980 - Doina Benea, Numerus Palmyrenorum Tibiscensium. Contribuții la istoria trupelor de palmyreni din Dacia, Apulum 18, 131-140.

Benea 1985 - Doina Benea, Numerus Maurorum Tibiscensium. Contribuții la istoria trupelor de mauri din Dacia, Banatica 8, 139-154.

Breeze 1971 - D. J. Breeze, Pay Grades and Ranks below the Centurionate, JRS 61, 130-135.

Cheesman 1914 - G. L. Cheesman, The Auxilia of the Roman Empire, Oxford.

Cichorius 1900 - C. Cichorius, Cohors, RE IV, 246-247.

Coulston 1985 - J. C. Coulston, Roman archery equipment, The Production and Distribution of Roman Military Equipment: Proceedings of the Second Roman Military Equipment Seminar (ed. M. C. Bishop), Oxford, BAR IS 275, 220-256.

Davies 1989 - R. Davies, Service in the Roman Army, London.

Dixon/Southern 1992 — Karen Dixon, Pat Southern, The Roman Cavalry, London.

Găzdac 1997 - C. Găzdac, Fighting Style of the Roman Cavalry in Dacia, ActaMN 34, 1, 151-166.

Goldsworthy 1996 - A. K. Goldsworthy, The Roman Army at War 100 BC - AD 200, Oxford.

Gudea 1979 - N. Gudea, The Defensive System of Roman Dacia, Britannia 10, 63-87.

Hyland 1990 - Ann Hyland, Equus: The Horse in the Roman World, London.

Hyland 1993 - Ann Hyland, Training the Roman Cavalry, London.

Isac 2003 - D. Isac, Castrul roman de la SAMVM - Căşeiu I, Cluj-Napoca.

Isac, Marcu 1999 - D. Isac, F. Marcu, Die Truppen im Kastell von Căşeiu: cohors II Br(ittanorum) milliaria und cohors I Britannica milliaria c. R. equitata Antoniniana, Limes 17 Zalău, 585-598.

Luttwak 1976 - E. Luttwak, The Grand Strategy of the Roman Empire, Baltimore-London.

Marcu 2004 - F. Marcu, Comments on the identity and deployment of cohortes I Brittonum, ActaMN 39-40, 1, 219-234.

Nemeth 2005 - E. Nemeth, Armata în sud-vestul Daciei romane/ Die Armee im Südwesten des römischen Dakien, Timişoara.

Peddie 1996 - J. Peddie, The Roman War Machine, Boduin.

Petolescu 1995a - C. Petolescu, Unitățile auxiliare din Dacia romană (I). Alae, SCIVA 46, 1, 35-50.

Petolescu 1995b - C. Petolescu, Unitățile auxiliare din Dacia Romană (II). Cohortes, SCIVA 46, 3-4, 237-275.

Petolescu 2002 - C. Petolescu, Auxilia Daciae. Contribuție la istoria militară a Daciei romane, Bucureşti.

Piso 1979 - I. Piso, Epigraphica (VI), Studii Clasice 18, 137-144.

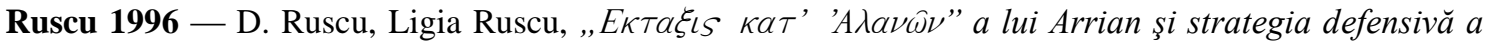
Imperiului Roman în epocă hadrianică, EN 6, 205-235.

Russu 1969 - I. I. Russu, Elemente syriene în Dacia carpatică, ActaMN 6, 167-186.

Southern 1989 - Pat Southern, The Numeri of the Imperial Roman Army, Britannia 20, 81-140.

Speidel 1973 - M. Speidel, The Pay of the Auxilia, JRS 63, 141-147.

Ureche 2009 - Ureche 2009, About the tactics and fighting particularity of the Auxiliary Infantry in Roman Dacia, ActaMN 43-44, I, 247-262.

Zahariade 1976 - M. Zahariade, Trupele de origine hispanică din Dacia, SCIVA 27, 2, 473-494. 


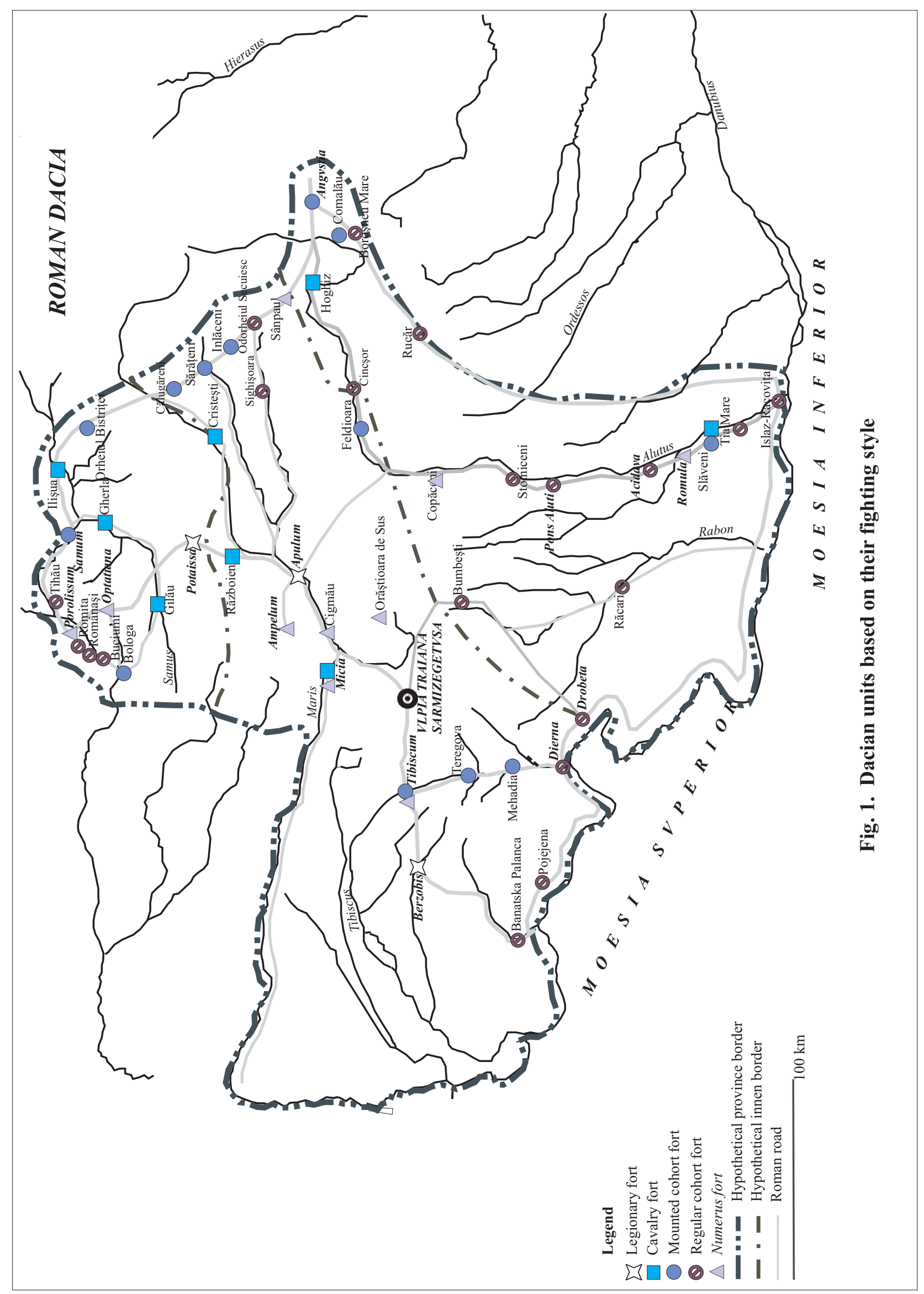




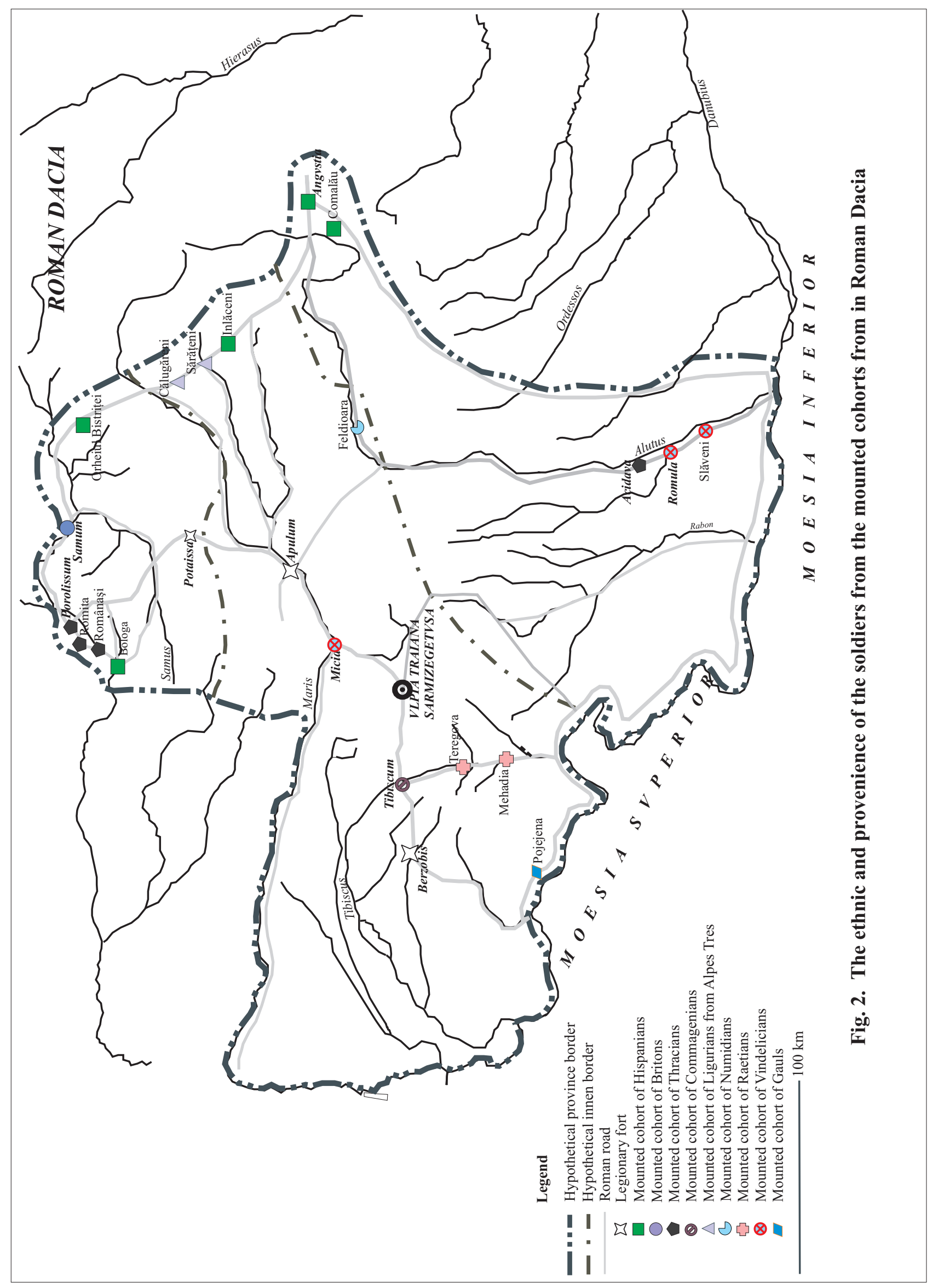

